\title{
Veterinary Pharmaceuticals Sold in Cattle Markets for the Management of Foot-and-Mouth Disease and Flies in Vina Division (Adamawa-Cameroon)
}

\author{
Sevidzem Silas Lendzele ${ }^{1 *}$, Mavoungou Jacques François ${ }^{1,2}$ and Mintsa Nguema Rodrigue ${ }^{2}$ \\ ${ }^{1}$ Ecole Doctorale des Grandes Ecoles (EDGE), Laboratoire d'Ecologie Vectorielle (LEV-IRET), Gabon \\ ${ }^{2}$ Institut de Recherche en Ecologie Tropicale (IRET-CENAREST), Gabon
}

Submission: February 13, 2019; Published: February 20, 2019

*Corresponding author: Sevidzem Silas Lendzele, Ecole Doctorale des Grandes Ecoles (EDGE), Laboratoire d'Ecologie Vectorielle (LEV-IRET), BP: 13354, Libreville, Gabon

\begin{abstract}
Foot-and-Mouth Disease is an important disease of even-toed domestic and wild animals. Farmer's knowledge about the disease and its management in the absence of a commercial vaccine as well as their knowledge on the existing potential vector (for FMD) such as the stable fly in the absence of mass fly control campaigns in Vina Division is necessary for the mitigation of FMD spread. A questionnaire survey was carried out in an FMD outbreak season in Vina, in August 2018 with target population including cattle owners/herders, drug sellers and veterinary chief of centers from Dang, Djalingo and Galdi cattle markets. According to cattle owners/herders, FMD outbreaks occurred at the end of the rainy season which corresponded to peak occurrence periods of stable flies in their herds. This observation creates a novel avenue on the potential transmission of FMD by the most frequent stomoxyidae and other flies in Vina Division. Antibiotics (especially Moore-Oxy ${ }^{\circledR}$ ) were highly solicited for FMD management while a combination of agricultural insecticides (DD force $₫+$ CYPERCOT $®$, PRIME FORCE $®+C Y P E R C O T ®$ and

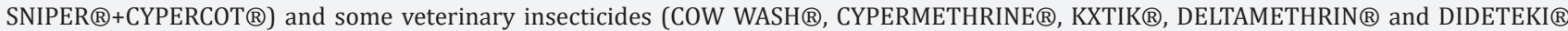
POURON) were used for fly control. Farmer's knowledge on the management of FMD and flies should not be neglected if vaccination and mass fly eradication campaigns respectively are to be initiated in Vina Division.
\end{abstract}

Keywords: Foot-and-Mouth Disease; Arthropod-vector; Transmission; Control-campaigns; Cattle markets; Vina Division

Abbreviations: FMD: Foot and Mouth Disease; LSD: Lumpy Skin Disease; FMDV: Foot and Mouth Disease Virus; TEC: Tsetse Eradication Campaign;

\section{Introduction}

Cattle breeding is the most dominant economic activity in the Adamawa region which is the number one cattle breeding region of Cameroon [1]. In Cameroon, cattle are regarded as a symbol of wealth. Increasing agricultural production and ameliorating the quality of milk and meat production are key to poverty alleviation and increasing food security in Africa especially Cameroon. The livestock industry of Cameroon is greatly affected by some major livestock and enzootic diseases such as: footand-mouth disease (FMD), lumpy skin disease (LSD), contagious bovine pleuro-pneumonia, bovine tuberculosis, brucellosis, peste des petits ruminant and rift valley fever (RVF) [2]. Among the major livestock diseases listed, FMD is a major topic of concern. FMD is a highly contagious viral vesicular disease affecting both domestic and wild even-toed ungulates species [3] of the order Artiodactylae $[4,5]$. This disease is caused by a virus with seven different serotypes: A, 0, C, SAT1, SAT2, SAT3 and Asia 1 [6] and each serotype can instigate indistinguishable clinical disease [7]. According to the report of the working document on the strategic plan for the control of FMD in Cameroon, the Adamawa region consists of $30 \%$ farmer organizations in the country with $23 \%$ of farmers whose cattle will likely to develop FMD two weeks after purchase, originates from Adamawa. The high cattle market density in the Adamawa region as well as their connectivity to the rest of the markets in Cameroon and neighboring countries indicates high animal contact and high risk of pathogens transmission via animal movement, personnel and vehicles. According to MINEPIA [1], such environments are targets for the execution of control measures such as implementing trade restrictions, vaccination and animal testing.

The role of some blood-sucking pasture flies in the epizootiology of several infectious diseases especially foot-and-mouth disease is not clear. From the economic entomological point of view, high levels of biting activity of stable flies have led to the substantial reductions in cattle meat and milk production [8-10]. For example, Barré [11] estimated in La Re'union that a total of 0.5-1 L of milk/cow/day was lost due to Stomoxys in highly infest- 
ed farms. In the study of grazing yearling steers/calves, Campbell et al. [12] observed an average loss of $0.2 \mathrm{~kg}$ in the weight gain of untreated animals versus insecticide-treated counterparts. This in tells considering the control of such pests if beef and dairy cattle are to be integrated in the livestock industry of Cameroon as a strategy to alleviate poverty in the nearest future. High density of stable fly occurs in cattle corrals and in wild life areas which harbor suitable breeding substrates for this fly population [13]. In Cameroon, Stomoxyidae is the most abundant group of biting flies while Musca spp. dominates as non-biting muscids in range lands $[14,15]$.

Transhumance and trade cattle from neighboring Central African Republic, Nigeria and Chad uses risk trajectories like those through the Gashaka Gumti Forest (besides the Faro), Mbere protected area, Waza National Park to enter the major cattle grazing lands of Cameroon. This risk occurs through the share of grazing areas and contact with wild animals such as buffalos which are natural reservoirs of the FMD. The wildlife/livestock interface is a risk to FMDV transmission as transmission was reported from buffalo to cattle by Jori et al. [16]. This risk increases when wild reservoirs of FMD cross borders to mingle with unvaccinated cattle. This mode of transmission remains poorly understood $[17,18]$. Entomological data in the wildlife-livestock interface of Adamawa plateau in the Faro Game Reserve and around the Kimbi Wild life zones in the North West of Cameroon revealed high apparent densities of Stomoxys, tabanids and glossines $[19,20]$, but these flies were suspected by these authors to transmit bovine trypanosomosis. The risk of mechanical transmission of foot-and-mouth disease virus (FMDV) by the most common blood-feeding Stomoxys niger niger (Diptera: Muscidae) in the field, revealed high infestation of range lands by this species and its high infection rate with the virus during the 2016 epidemic in Ngaoundere [15]. This mechanical vector is involved in the contaminative transmission of FMDV from infected cattle to susceptible livestock during outbreaks in a hyper-endemic setting [15]. From this preliminary experience, the scenario on the transmission of the FMD from wildlife to cattle and vice versa can otherwise be explained as 'picking-up the virus from one host to the next during a rapid, interruptive and repeated blood meal of mechanical vectors like stable fly [21].

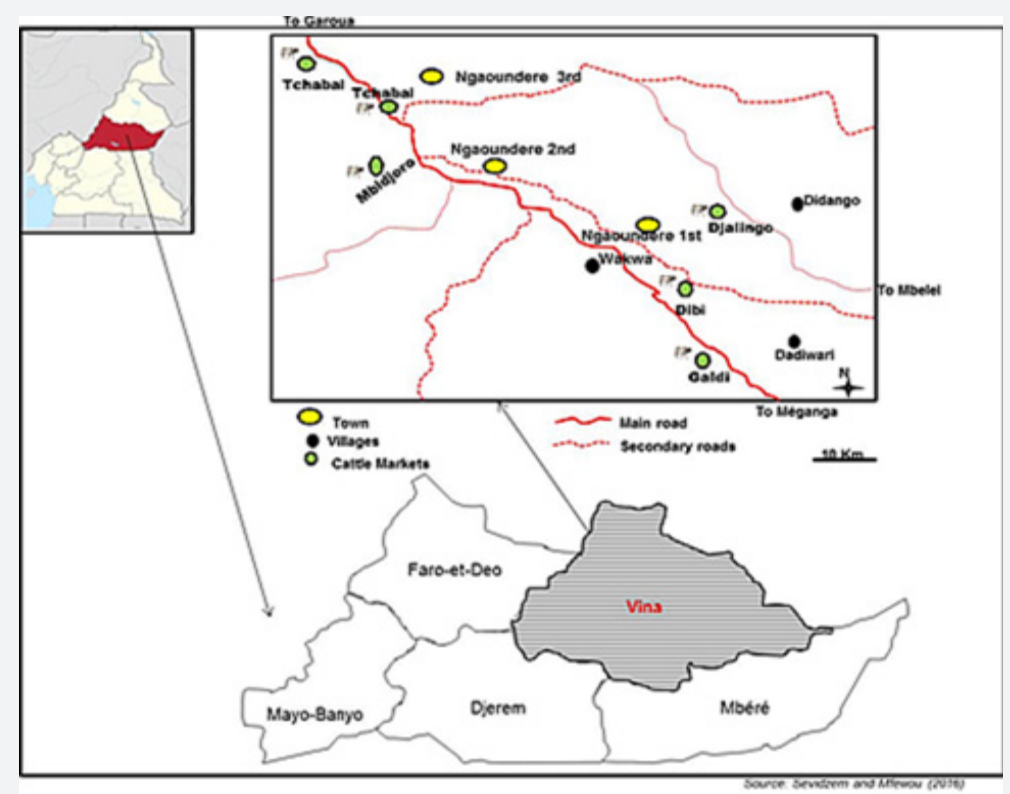

Figure 1: Map of Vina division showing the various cattle markets.

The last Tsetse Eradication Campaign (TEC) in Cameroon was in 1994 and only focused on tsetse elimination from major cattle rearing areas. The activities of the special mission for the eradication of glossines known by its French acronym as MSEG are currently focusing her activities on glossines. After the 1994 TEC, the Adamawa plateau was sub-divided into: tsetse-infested, non-infested and buffer zone. The activities of the MSEG are ongoing with focus in the control of glossines in infested areas of the Adamawa and Far North regions. The Vina division is considered as a tsetse free zone of the Adamawa plateau and no intervention campaigns are ongoing. From our current entomological data of Ngaoundere, stable flies are the most abundant group in the apparent absence of glossines [15]. Management of tabanids and Stomoxys flies in Vina is carried out by farmers using insecticides and bush fires. FMD occurs every year in this Division with no vaccination campaigns. The management of FMD is carried out by Farmers themselves using antibiotics, anti-parasitics, anti-inflammatories and traditional preparations. Based on the medico-veterinary importance of stable flies and other biting Dipterans, vector intervention units such as the MSEG need to include them in their activities and not only focus on glossines which are apparently absent in most areas in the Adamawa plateau. 


\section{Journal of Dairy \& Veterinary Sciences}

According to Goswami \& Sagar [22], improving farmers' knowledge and identifying the gaps regarding FMD epidemiology as well as restricting movement of animals are critical activities for an effective FMD response effort. To improve on the knowledge of the epidemiology of FMD in Vina division of the Adamawa plateau of Cameroon, we designed a questionnaire survey to evaluate on the indigenous breeder's own knowledge on FMD and potential fly-vectors as well as the use of veterinary pharmaceuticals to manage the disease and flies in sites with no history of mass vaccination and mass fly eradication campaigns.

\section{Materials and Methods}

\section{Study Area}

The Vina division was found in the Adamawa Region of North Cameroon has a surface area of $17196 \mathrm{~km}^{2}$. It was located within the following geographical limits: Latitude $07^{\circ} 21^{\prime} 378^{\prime \prime} \mathrm{N}$ and Longitude $013^{\circ} 32^{\prime}$ 695" E (Figure 1). It possessed a Soudano-Guinean climate that was modulated by altitude. More than $90 \%$ of the cattle in this division were sedentary and during the rainy season, they were sedentary on pastures on the plateau. In the dry season, some herds went on transhumance to the alluvial plains with some few heads left around homesteads to generate milk and meat for the family. This division hosts the main cattle market of the region, located in a village called Mbidjoro in Ngaoundere. Market days in the region operated on weekly basis.

\section{Questionnaire Survey}

A semi-structured questionnaire survey was conducted with target population consisting of cattle owners/herders, drug sellers and veterinary chief of centers during cattle market days. The questionnaire sheet consisted of the following elements: sociodemographic information, husbandry level, knowledge of herdTable 1: Economic value of cattle breeding as well as frequency, seasona

\begin{tabular}{|c|c|c|c|c|c|c|c|c|}
\hline Parameters & Mbidjoro & Tchabal & Djalingo & Dang & Galdi & Dibi & Total & $\%$ \\
\hline \multicolumn{2}{|c|}{ Livestock contribution to Economy } & \multicolumn{7}{|c|}{ Chi-square $=10.126, \mathrm{df}=10, \mathrm{p}$-value $=0.4295$} \\
\hline High & 23 & 19 & 20 & 9 & 13 & 17 & 101 & 83.47 \\
\hline Medium & 3 & 3 & 2 & 4 & 1 & 2 & 15 & 12.39 \\
\hline Low & 3 & 0 & 0 & 1 & 0 & 1 & 5 & 4.13 \\
\hline Total & 29 & 22 & 22 & 14 & 14 & 20 & 121 & 100 \\
\hline \multicolumn{2}{|c|}{ FMD frequency } & \multicolumn{7}{|c|}{ Chi-square $=10.126, \mathrm{df}=10, \mathrm{p}$-value $=0.4295$} \\
\hline One time per year & 10 & 10 & 7 & 5 & 6 & 6 & 44 & 36.36 \\
\hline Two times per year & 9 & 12 & 14 & 8 & 7 & 12 & 62 & 51.23 \\
\hline Three times per year & 4 & 0 & 0 & 1 & 0 & 2 & 7 & 5.78 \\
\hline Five times per year & 2 & 0 & 1 & 0 & 1 & 0 & 4 & 3.30 \\
\hline$>$ Five times per year & 4 & 0 & 0 & 0 & 0 & 0 & 4 & 3.30 \\
\hline Total & 29 & 22 & 22 & 14 & 14 & 20 & 121 & 100 \\
\hline \multicolumn{2}{|c|}{ FMD seasonal occurrence } & \multicolumn{7}{|c|}{ Chi-square $=24.001, \mathrm{df}=15, \mathrm{p}$-value $=0.06508$} \\
\hline End rainy season & 21 & 19 & 20 & 11 & 9 & 16 & 96 & 79.33 \\
\hline Begining rainy season & 6 & 3 & 1 & 0 & 4 & 2 & 16 & 13.22 \\
\hline End rainy+begining dry season & 2 & 0 & 0 & 0 & 0 & 0 & 2 & 1.65 \\
\hline Begining of dry season & 0 & 0 & 1 & 3 & 1 & 2 & 7 & 5.78 \\
\hline Total & 29 & 22 & 22 & 14 & 14 & 20 & 121 & 100 \\
\hline
\end{tabular}

ers on the subject (FMD or stomoxyids), perceived susceptibility grading of FMD, perceived severity grading of FMD, seasonal occurrence of FMD and stomoxyids, transmission route of FMD, methods of FMD management and vector control, veterinary pharmaceuticals sold in cattle markets for FMD management and vector control. The questionnaire sheets were filled through discussions with the individuals of the target population in the following areas: Mbidjoro, Tchabal, Dang, Djalingo, Dibi and Galdi. Only individuals who were willing to participate were included in the study. The questions were asked in Fulfulde with the assistance of a veterinary technician who is a local of the region.

\section{Statistical Analysis}

Data was analyzed using the R statistical software. The chisquare test was used to compare the responses of herders/cattle owners in the different sites (cattle markets).

\section{Results}

\section{Herders' responses on the Economic value of cattle breeding as well as frequency, seasonal trend and eco- nomic impact of FMD}

In total, 500 questionnaire sheets were prepared and 121 of them were filled during the survey in the major cattle markets of Vina division. The number of sheets filled was from individuals from the target population that were available at the various cattle markets. From findings, all herders interviewed (100\%) knew FMD, colloquially called 'Njobu' or 'Bauru' in Fulfulde. 83.47\% of the herders perceived high economic value of livestock rearing, $12.31 \%$ perceived medium economic value and only $4.13 \%$ perceived low economic value concerning cattle breeding. There was no significant difference (Chi-square $=10.126$, $\mathrm{df}=10, \mathrm{p}=$ 0.4295 ) in herder responses in cattle breeding between sites. nal trend and economic impact of FMD. 


\section{Journal of Dairy \& Veterinary Sciences}

\begin{tabular}{|c|c|c|c|c|c|c|c|c|}
\hline \multicolumn{2}{|c|}{ FMD economic impact } & \multicolumn{4}{|c|}{ Chi-square = 15.08, df = 10, p-value = 0.1292 } \\
\hline High & 15 & 17 & 11 & 9 & 11 & 16 & 79 & 65.28 \\
\hline Low & 3 & 4 & 4 & 0 & 1 & 2 & 16 & 13.22 \\
\hline Medium & 10 & 1 & 6 & 5 & 2 & 2 & 26 & 18.18 \\
\hline Total & 28 & 22 & 21 & 14 & 14 & 20 & 121 & 100 \\
\hline
\end{tabular}

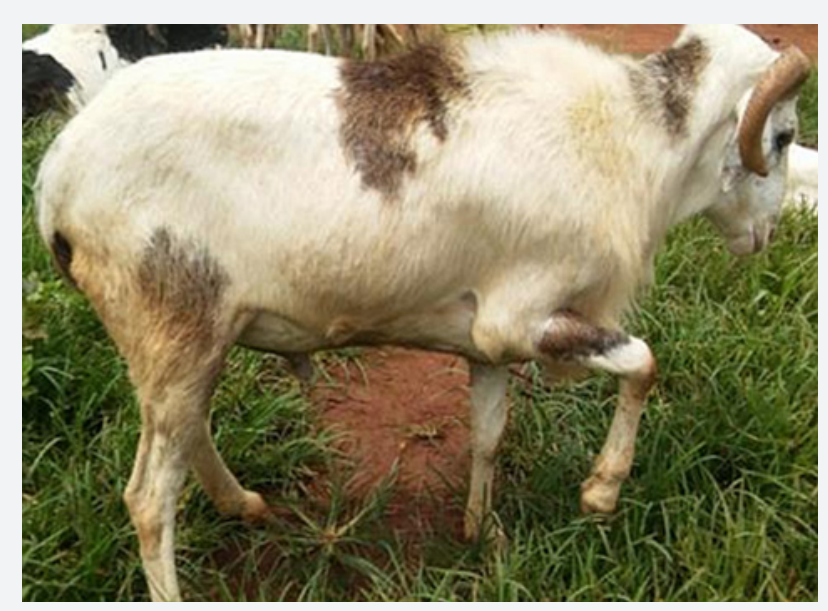

Figure 2: Clinical case of FMD in sheep identified at the Dang market.

Highest outbreaks frequency was reported by $51.24 \%$ of the respondents to be twice a year (Table 1). It appeared that this frequency of occurrence did not differ statistically (Chi-square $=10.126, \mathrm{df}=10, \mathrm{p}=0.4295$ ) with site. Herders responded that a high $(65.29 \%)$ production loss was caused by FMD (Table 1 ). There was no statistically significant difference (Chi-square = $15.08, \mathrm{df}=10, \mathrm{p}=0.1292$ ) in economic impact grading with site. Outbreak was seasonal and most of the herders (79.33\%) sig- naled that the onset of cases was at the end of the rainy season (Table 1) in the months of August, September and October. In August 2018, a sheep with lameness and inter-digital leisions (Figure 2), characteristic of FMD clinical sign was identified in the Dang small ruminant section of the cattle market. The owner of the sheep reported a current outbreak in his herd around Borongo where eight sheep were suffering from FMD out of 34 giving an observed prevalence rate of $23.53 \%$.

\section{Herders responses on the transmission and management of FMD}

Table 2: Transmission and management methods of FMD.

\begin{tabular}{|c|c|c|c|c|c|c|c|c|}
\hline Parameters & Mbidjoro & Tchabal & Djalingo & Dang & Galdi & Dibi & Total & $\%$ \\
\hline FMD Transmission & & \multicolumn{4}{|c|}{ Chi-square $=45.139, \mathrm{df}=40, \mathrm{p}$-value $=0.2658$} & & & \\
\hline Air & 3 & 2 & 1 & 1 & 0 & 2 & 9 & 7.43 \\
\hline Soil & 2 & 3 & 0 & 0 & 0 & 0 & 5 & 4.13 \\
\hline Birds & 4 & 6 & 3 & 2 & 5 & 2 & 22 & 18.18 \\
\hline Animals in contact & 8 & 9 & 9 & 6 & 6 & 11 & 49 & 40.49 \\
\hline Personnel & 0 & 0 & 1 & 0 & 0 & 0 & 1 & 0.82 \\
\hline Vehicles & 0 & 0 & 1 & 0 & 0 & 0 & 1 & 0.82 \\
\hline Flies & 5 & 0 & 3 & 2 & 0 & 2 & 12 & 9.91 \\
\hline Milk & 1 & 2 & 3 & 3 & 2 & 2 & 13 & 10.74 \\
\hline No idea & 6 & 0 & 1 & 0 & 1 & 1 & 9 & 7.43 \\
\hline Total & 29 & 22 & 22 & 14 & 14 & 20 & 121 & 100 \\
\hline \multicolumn{2}{|c|}{ FMD management Methods } & & \multicolumn{4}{|c|}{ Chi-square $=144.63, \mathrm{df}=55, \mathrm{p}$-value $=5.455 \mathrm{e}-10$} & & \\
\hline Procaine & 20 & 8 & 12 & 2 & 8 & 12 & 62 & 51.23 \\
\hline Oxytetracycline & 0 & 0 & 2 & 0 & 0 & 0 & 2 & 1.65 \\
\hline Penincillin & 0 & 0 & 0 & 0 & 0 & 1 & 1 & 0.82 \\
\hline Medicinal plants & 5 & 5 & 0 & 1 & 0 & 2 & 13 & 10.74 \\
\hline
\end{tabular}




\section{Journal of Dairy \& Veterinary Sciences}

\begin{tabular}{|c|c|c|c|c|c|c|c|c|}
\hline Procaine+herd isolation & 1 & 0 & 0 & 3 & 0 & 0 & 4 & 3.30 \\
\hline Procaine +hygiene & 1 & 0 & 0 & 0 & 1 & 0 & 2 & 1.65 \\
\hline Procaine+medicinal pants & 0 & 9 & 1 & 0 & 3 & 3 & 16 & 13.22 \\
\hline Procaine+oxytetracycline & 0 & 0 & 4 & 0 & 2 & 2 & 8 & 6.61 \\
\hline Hygiene & 1 & 0 & 2 & 0 & 0 & 0 & 3 & 2.47 \\
\hline Oxytetracycline+Ivermectin & 0 & 0 & 1 & 0 & 0 & 0 & 1 & 0.82 \\
\hline Herd isolation & 1 & 0 & 0 & 5 & 0 & 0 & 6 & 4.95 \\
\hline Herd isolation + medicinal plants & 0 & 0 & 0 & 3 & 0 & 0 & 3 & 2.47 \\
\hline Total & 29 & 22 & 22 & 14 & 14 & 20 & 121 & 100 \\
\hline
\end{tabular}

The most common mode of transmission of FMD was through animal contact $(40.49 \%)$, followed by birds (18.18\%) and milk $(10.74 \%)$ and these responses did not differ significantly (Chisquare $=45.139, \mathrm{df}=40, \mathrm{p}=0.2658$ ) with sites (Table 2 ). Herders explained that during outbreaks, the contact of an infected herd with a non-infected one resulted in the spread of FMD. A significant number of respondents highlighted the role of pasture birds in the spread of the virus during outbreaks. The control methods for the disease was grouped into five: anesthetics (procaine), antibiotics (penicillin and oxytetracycline), antiparasitic (diminazene and ivermectin), hygiene (cleaning of wounds) and herd isolation. Procaine was the most commonly used management option (51.23\%) followed by procaine+medicinal plants
$(13.22 \%)$ and medicinal plants (10.74\%). However, there was a statistically significant difference (Chi-square $=144.63, \mathrm{df}=$ 55 , -value $=5.455 \mathrm{e}-10$ ) in the management methods with site (Table 2). The significant difference was as a result of Tchabal where breeders rather used procaine+medicinal plants. It was interesting to know that a significant number of respondents did not border to treat the disease since they considered that there was no vaccine and that the clinical signs will disappear with time. It was interesting to know that $15.70 \%$ of the respondents purchased their antibiotics, anesthetics and antiparasitic from veterinary pharmacies and most of them were large scale farmers (ranch owners) and more than $80 \%$ of them purchased from cattle markets (small-scale farmers).

Stable fly's Knowledge, frequency, seasonal trend, economic impact and insecticide usage

Table 3: Stable fly's Knowledge, frequency, seasonal trend, economic impact and insecticide usage.

\begin{tabular}{|c|c|c|c|c|c|c|c|c|}
\hline Parameters & Mbidjoro & Tchabal & Djalingo & Dang & Galdi & Dibi & Total & $\%$ \\
\hline Knowledge & & \multicolumn{5}{|c|}{ Chi-square $=13.922, \mathrm{df}=5, \mathrm{p}$-value $=0.01611$} & & \\
\hline Yes & 16 & 18 & 16 & 13 & 11 & 19 & 93 & 76.85 \\
\hline No & 13 & 4 & 6 & 1 & 3 & 1 & 28 & 23.14 \\
\hline Total & 29 & 22 & 22 & 14 & 14 & 20 & 121 & 100 \\
\hline Season & & \multicolumn{6}{|c|}{ Chi-square $=69.741, \mathrm{df}=20, \mathrm{p}$-value $=2.008 \mathrm{e}-07$} & \\
\hline Begining rainy season & 10 & 10 & 4 & 0 & 5 & 13 & 42 & 34.71 \\
\hline End rainy season & 1 & 1 & 7 & 10 & 6 & 3 & 28 & 23.14 \\
\hline Begining dry season & 1 & 3 & 2 & 1 & 1 & 3 & 11 & 9.09 \\
\hline End dry season & 0 & 4 & 3 & 2 & 0 & 0 & 9 & 7.43 \\
\hline No idea & 17 & 4 & 6 & 1 & 2 & 1 & 31 & 25.61 \\
\hline Total & 29 & 22 & 22 & 14 & 14 & 20 & 121 & 100 \\
\hline $\begin{array}{l}\text { Stomoxys economic impact } \\
\text { relative to other biting flies }\end{array}$ & & \multicolumn{6}{|c|}{ Chi-square $=61.998, \mathrm{df}=15, \mathrm{p}$-value $=1.14 \mathrm{e}-07$} & \\
\hline High & 3 & 14 & 6 & 7 & 4 & 7 & 41 & 33.88 \\
\hline low & 5 & 1 & 9 & 0 & 4 & 12 & 31 & 25.61 \\
\hline medium & 4 & 3 & 1 & 6 & 3 & 0 & 17 & 14.04 \\
\hline no idea & 17 & 4 & 6 & 1 & 3 & 1 & 32 & 26.44 \\
\hline Total & 29 & 22 & 22 & 14 & 14 & 20 & 121 & 100 \\
\hline Insecticide usage & & \multicolumn{6}{|c|}{ Chi-square $=76.069, \mathrm{df}=35, \mathrm{p}$-value $=7.177 \mathrm{e}-05$} & \\
\hline $1 \mathrm{xWrs}+1 \mathrm{xWds}$ & 1 & 2 & 9 & 6 & 5 & 5 & 28 & 23.14 \\
\hline $2 x W r s+1 x W d s$ & 6 & 9 & 5 & 8 & 9 & 9 & 46 & 38.01 \\
\hline $4 \mathrm{xWrs}+1 \mathrm{xWds}$ & 1 & 1 & 0 & 0 & 0 & 0 & 2 & 1.65 \\
\hline $3 x W r s+2 x W d s$ & 1 & 5 & 2 & 0 & 0 & 1 & 9 & 7.43 \\
\hline $3 x W r s+1 x W d s$ & 4 & 4 & 1 & 0 & 0 & 1 & 10 & 8.26 \\
\hline
\end{tabular}




\begin{tabular}{|c|c|c|c|c|c|c|c|c|}
\hline 2xWrs+2xWds & 0 & 0 & 1 & 0 & 0 & 0 & 1 & 0.82 \\
\hline 4xWrs+2xWds & 0 & 0 & 1 & 0 & 0 & 0 & 1 & 0.82 \\
\hline No application & 16 & 1 & 3 & 0 & 0 & 4 & 24 & 19.83 \\
\hline Total & $\mathbf{2 9}$ & $\mathbf{2 2}$ & $\mathbf{2 2}$ & $\mathbf{1 4}$ & $\mathbf{1 4}$ & $\mathbf{2 0}$ & $\mathbf{1 2 1}$ & $\mathbf{1 0 0}$ \\
\hline
\end{tabular}

Entomological findings showed that $76.86 \%$ of the respondents could identify a stable fly (locally known as "boubi pettel" meaning small flies) and could even show it sucking blood during the questionnaire sessions (Table 3). However, there was a statistically significant difference (Chi-square $=13.922, \mathrm{df}=5$, $\mathrm{p}=0.01611$ ). The locals (Fulbe) distinguished it from tabanids (locally known as "boubi manga" meaning large flies) in terms of size. Outbreaks of stable flies generally occurred at the beginning of the rainy season $(34.71 \%)$, followed by end of rainy season (23.14\%). It was interesting to know that $25 \%$ of the herders did not have any idea on the seasonal occurrence of stable flies (Table 3). There was no statistically significant difference (Chisquare $=69.741, \mathrm{df}=20, \mathrm{p}=2.008 \mathrm{e}-07$ ) on the finding with season.

From the herder's responses on the impact of the occurrence of stable flies on livestock breeding, majority reported a high impact (33.88\%) followed by low impact (25.61\%), medium $(14.04 \%)$ and it was interesting to know that $26.44 \%$ did not perceive any impact of stable flies in their herds. However, there was a statistically significant difference (Chi-square $=61.998$, $\mathrm{df}=15, \mathrm{p}=1.14 \mathrm{e}-07$ ) in herder's responses on impact of stable flies with site. Based on the insecticide usage, herders mostly (38.01\%) sprayed their animals with insecticides twice a week in the rainy season and once a week in the dry season, followed by $23.14 \%$ who applied once per week in the rainy season and once per week in the dry season. It was interesting to know that $19.83 \%$ did not use insecticides. However, there was a statistically significant difference (Chi-square $=76.069, \mathrm{df}=35, \mathrm{p}=7.177 \mathrm{e}-$ 05 ) in herders' knowledge on insecticide application with sites.

According to Table 3, most outbreaks of stable flies in Dang, Djalingo and Galdi were noticed at the end of the rainy season and this information corresponded with the seasonal trend responses of the herders concerning FMD in these same areas. This indicated that high densities of stable flies led to the high occurrence of FMD in Djalingo, Dang and Galdi. High stable fly frequencies in herds were reported by $47.11 \%$ of the respondents. Majority of the farmers in Mbidjoro had no idea on stable flies but the respondents of the other cattle markets surveyed reported high occurrence of stable flies in their farms.

\section{Knowledge of respondents on stable flies based on the different age cohorts}

The morphological identification of stable flies on a standing cattle in the cattle market by cattle owners and herders differed as such: young adults [18-35] $(\mathrm{n}=61$ : yes $=47$, no=14, 50.4\%), middle aged [36-55] $(n=42$ : yes=31, no=11, 34.7\%) and older adults [>55] ( $n=18$ : yes=14, no=4, 14.9\%) (Figure 3). It can be deduced from this finding that, the economic impact caused by tsetse flies in the past has made elderly farmers to focus on them and neglect other biting flies like stable flies.

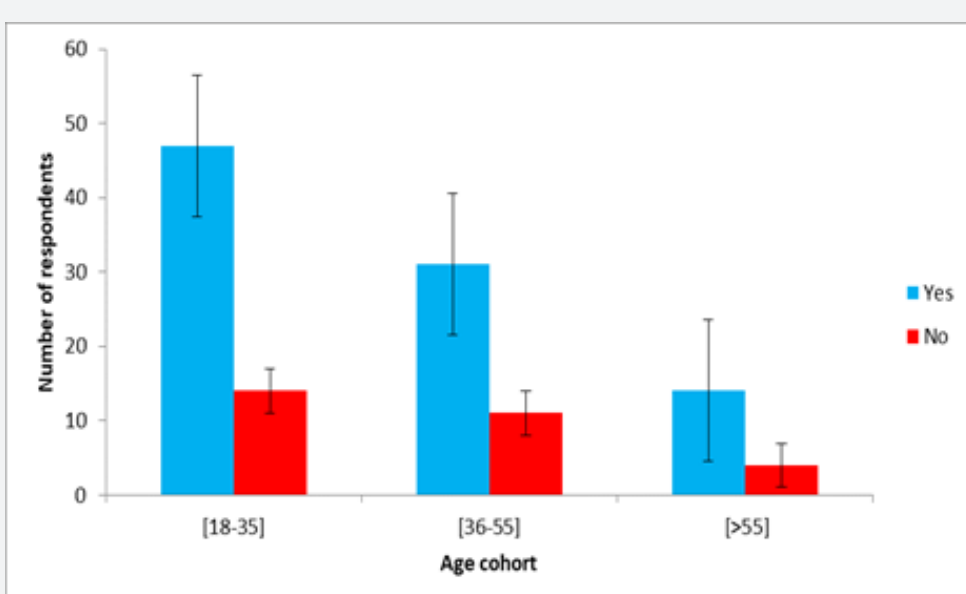

Figure 3: Farmer's Knowledge on stable flies based on age.

Prescription of anti-parasitics, antibiotics and anti-inflammatories to breeders by drug sellers

The most frequently prescribed drugs for the management of FMD were antibiotics followed by antiparasitic and lastly by anti-inflammatories (Figure 4). Majority of the drug sellers prescribed antibiotics precisely Moore Oxy® (Oxytetracyclin) whose common name was boldly written on the drug-bottle-label as "Likki Bauru" in Fulfude, meaning FMD drug. In Dibi, $62 \%$ the drug vendors prescribed drugs with anti-inflammatory properties example Bullvet@ (Dexamethasone 0.2\%) (Figure 5). In Tchabal, $100 \%$ of the management was carried out using different antibiotic brands ranging from Combikel ${ }^{\circ}$, Oxytetra- 


\section{Journal of Dairy \& Veterinary Sciences}

cyclines, procaine penicillin/procaine penicillin 4 Mega®, Pen- $\quad$ management. Most of the drugs sold in the cattle markets carStrep® 20/20, Peni ${ }^{\circledR} 40$ (Table 4). In Dibi, drug sellers testified ried labels of pharmaceutical laboratories from Nigeria, Belgium, that herders combined procaine and Vitamin B complex for FMD France, India and China.

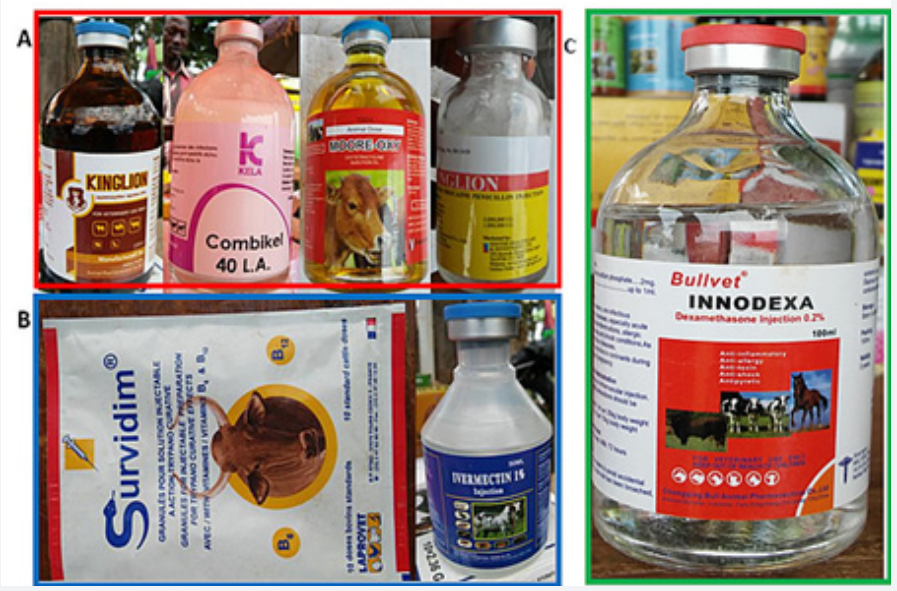

Figure 4: Drugs prescribed by drug sellers to cattle owners for the management of FMD

A: Antibiotics (red frame) B: Antiparasitic (blue frame) and C: Anti-inflammatory (green frame)

Table 4: List of common drugs prescribed by drug sellers to breeders for FMD management.

\begin{tabular}{|c|c|c|c|c|}
\hline Action & Trade Name & Pharmaceutical Name/Composition & Country & Cost/FCFA \\
\hline \multirow[t]{12}{*}{ Antibiotics } & Peni $40 ®$ & $\begin{array}{c}\text { Procaine Penicillin }(200 \mathrm{mg} / \mathrm{ml})+\text { Sihydrostreptomycin } \\
\text { (200000.u.i. } / \mathrm{ml})\end{array}$ & China & 3000 \\
\hline & Moore $0 x y \circledast$ & Oxytetracycline Injection 5\% & China & 2500 \\
\hline & King Lion ${ }^{\circledR}$ & $\begin{array}{l}\text { Fortified Procaine Penicillin Injection (Procaine penicillin+benzyl } \\
\text { penicillin) }\end{array}$ & Nigeria & 250 \\
\hline & Penstrep20/20® & Penicillin+ Streptomycin & China & 3000 \\
\hline & Combikel ${ }^{8} 40$ L. A & $\begin{array}{l}\text { Benzyl Penicillin procaine (120000 I. U) + Benzathine benzyl } \\
\text { penicillin (80000 I U) +sulphate dihydrostreptomycin }(200 \mathrm{mg})\end{array}$ & Belgium & 4500 \\
\hline & Rasomycin $®$ L. A & Oxytetracycline $20 \%$ & China & 2500 \\
\hline & Oxymed® 5\% & Oxytetracycline & China & 1000 \\
\hline & Oxytop $® 20 \%$ & Oxytetracycline & China & 2000 \\
\hline & Tetranor $®$ L.A 20 & Oxytetracycline dihydrate $20 \%$ & China & 2500 \\
\hline & $\begin{array}{l}\text { Procaine Penicillin Injec- } \\
\text { tion BP } 4 \text { MEGA® }\end{array}$ & Procaine Penicillin & China & 400 \\
\hline & PENSTREP $® 400$ & Penicillin+ Streptomycin & Belgium & 3500 \\
\hline & OXYNEET® 5\% & Oxy $5 \%$ & Nigeria & 2000 \\
\hline \multirow[t]{13}{*}{ Antiparasitic } & Ivermectin $® 1 \%$ Injection & Ivermectin & China & 2000 \\
\hline & Ivoron $\AA$ & Ivermectin $1 \%$ & Pakistan & 2000 \\
\hline & Ivoron super ${ }^{\circledR}$ & Ivermectin & China & 2000 \\
\hline & Abumectin $\AA$ & Ivermectin & China & 2000 \\
\hline & IVERSAINT® L.A- 4\% & Ivermectine & China & 2000 \\
\hline & Ivermectin ${ }^{\circledR} 1 \%$ Injection & Ivermectin $1 \%$ & China & 2000 \\
\hline & IverVet $囚 1 \%$ & Ivermectin & China & 2500 \\
\hline & IVANOR® & Ivermectin & Nigeria & 2500 \\
\hline & IVERSUPER $® 2 \%$ Plus & Ivermectin Injection $2 \%$ & Nigeria & 1500 \\
\hline & iverGLORY® & Ivermectin $1 \% \mathrm{w} / \mathrm{v}$ & China & 4000 \\
\hline & INNODEXA® & Dexamethasone & China & 2500 \\
\hline & SURVIDIM ${ }^{\circledR}$ & Diminazene diaceturate + vit B12+vit B6+Antipyrine & France & 2500 \\
\hline & Diminazene ${ }^{\circledR}$ & Diminazene & Cameroon & 1500 \\
\hline
\end{tabular}


Journal of Dairy \& Veterinary Sciences

\begin{tabular}{|l|c|c|c|c|}
\hline $\begin{array}{c}\text { Anti-inflamma- } \\
\text { tories }\end{array}$ & Diclodex $®$ & Diclofenac 2.5\%+ Dexamethason $0.2 \%$ Injection & China & 2000 \\
\hline & Bullvet ${ }^{\circledR}$ & $\begin{array}{c}\text { Dexamethason 0.2\% (anti-inflammatory, anti- allergy, anti- toxin, } \\
\text { anti-shock, anti- pyretic) }\end{array}$ & Nigeria & 2500 \\
\hline & Dexanor ${ }^{0} 0.2$ & $0.2 \%$ Dexamethasone & China & 2000 \\
\hline
\end{tabular}

\section{Prescription of agricultural insecticides for veterinary use by drug sellers to cattle owners}

Table 5: Common veterinary and agricultural insecticides prescribed by drug sellers to breeders in the study markets.

\begin{tabular}{|c|c|c|c|c|c|c|c|}
\hline & Trade Name & Chemical Name/Composition & Local Name & Origin & Action & Country/Pharmacy & Cost (FCFA) \\
\hline & KXTIK® 50 & Lamda-Cyhalothrin 50 & Tegal & $\begin{array}{l}\text { Afrique SANTE } \\
\text { Animale }\end{array}$ & Insecticide & China & 8000 \\
\hline & $\begin{array}{l}\text { Deltamethrin }{ }^{\circledR} \\
\text { solution } 5 \%\end{array}$ & Deltamethrin & Tegal & $\begin{array}{l}\text { Afrique SANTE } \\
\text { Animale }\end{array}$ & Insecticide & China & 8000 \\
\hline \multirow[t]{5}{*}{$\begin{array}{l}\text { Veter- } \\
\text { inary }\end{array}$} & COW WASH ${ }^{\circledR}$ & Fipronil & Tegal & PHARMAVET & $\begin{array}{l}\text { Insecticide, } \\
\text { Acaricide }\end{array}$ & $\begin{array}{l}\text { PHARMAVET-INTER- } \\
\text { AGRI, Cameroon }\end{array}$ & 3500 \\
\hline & $\begin{array}{l}\text { DIDETEKI }{ }^{\circledR} \\
\text { POUR ON }\end{array}$ & Cypermethrin & Tegal & CAPHAVET & $\begin{array}{l}\text { Insecticide, } \\
\text { Acaricide }\end{array}$ & / & 6000 \\
\hline & $\begin{array}{l}\text { Cyperme- } \\
\text { thrine }{ }^{\circledR}\end{array}$ & Cypermethrine $10 \%$ & Tegal & $\begin{array}{l}\text { Afrique SANTE } \\
\text { Animale }\end{array}$ & $\begin{array}{l}\text { Insecticide, } \\
\text { Acaricide }\end{array}$ & China & 8000 \\
\hline & PRIME FORCE® & $\begin{array}{c}\text { DDVP (2,3 dichlorovinyl } \\
\text { dimethyl phosphate) } 1000 \\
\text { G/C EC }\end{array}$ & Tegal & Nigeria & Insecticide & $\begin{array}{l}\text { Amarshal com.Agro } \\
\quad \& \text { Tec. LTD }\end{array}$ & 6000 \\
\hline & SNIPER $®$ & $\begin{array}{c}\text { DDVP (2,3 dichlorovinyl } \\
\text { dimethyl phosphate) } 1000 \\
\text { G/C EC }\end{array}$ & Tegal & Nigeria & Insecticide & $\begin{array}{l}\text { Saro Agro sciences } \\
\text { LTD }\end{array}$ & 1000 \\
\hline \multirow[t]{3}{*}{$\begin{array}{l}\text { Agri- } \\
\text { cul- } \\
\text { tural } \\
\end{array}$} & BEST® & Cypermethrine $10 \%$ E.C & Tegal & Nigeria & Insecticide & Nigeria & 4000 \\
\hline & DD Force ${ }^{\circledR}$ & $\begin{array}{l}\text { Chinomethionat+ Dichlorflu- } \\
\text { anid }\end{array}$ & Tegal & Nigeria & $\begin{array}{l}\text { Insecticide, } \\
\text { Acaricide }\end{array}$ & China & 1000 \\
\hline & CYPERCOT® & Cypermethrine 100 E.C & Tegal & $\begin{array}{l}\text { Garoua Cam- } \\
\text { eroon }\end{array}$ & Insecticide & AFCOTT Cam Sarl & 8000 \\
\hline
\end{tabular}

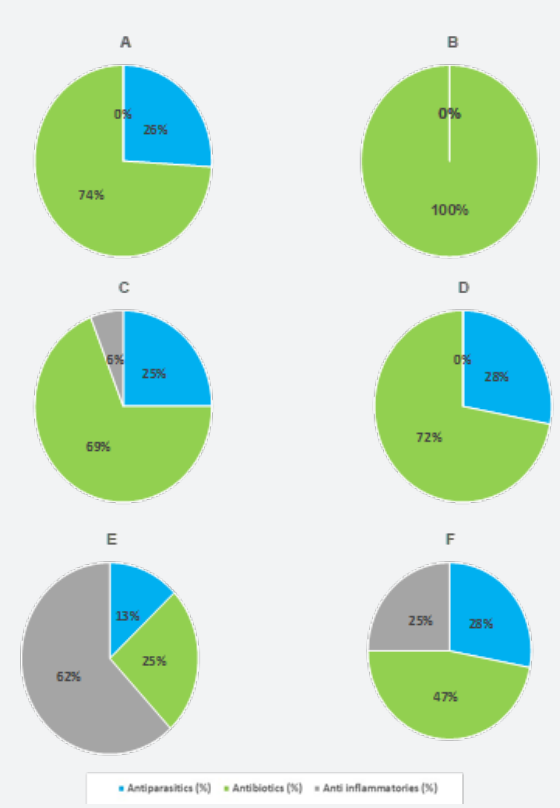

Figure 5: Proportion of drug sellers prescribing the different groups of drugs for FMD.

A: Mbidjoro; B: Tchabal; C: Galdi; D: Djalingo; E: Dibi; F: Dang

The drug sellers in Dang (56\%), Djalingo (73\%) and Dibi PRIME FORCE®, DD Force $₫$, BEST $₫$ and CYPERCOT® for fly (52\%) recommended agricultural insecticides like SNIPER®, management (Figures 6B,7 \& Table 5). In Galdi (83\%), Mbidjoro 
(55\%) and Tchabal (60\%), drug vendors rightly prescribed veterinary insecticides for veterinary use (insecticide and acaricide) (Figures 6A,7). Some of the common insecticides encoun- tered included, COW WASH®, CYPERMETHRINE®, KXTIK®, DELTAMETHRIN® and DIDETEKI $®$ POURON (Table 5).

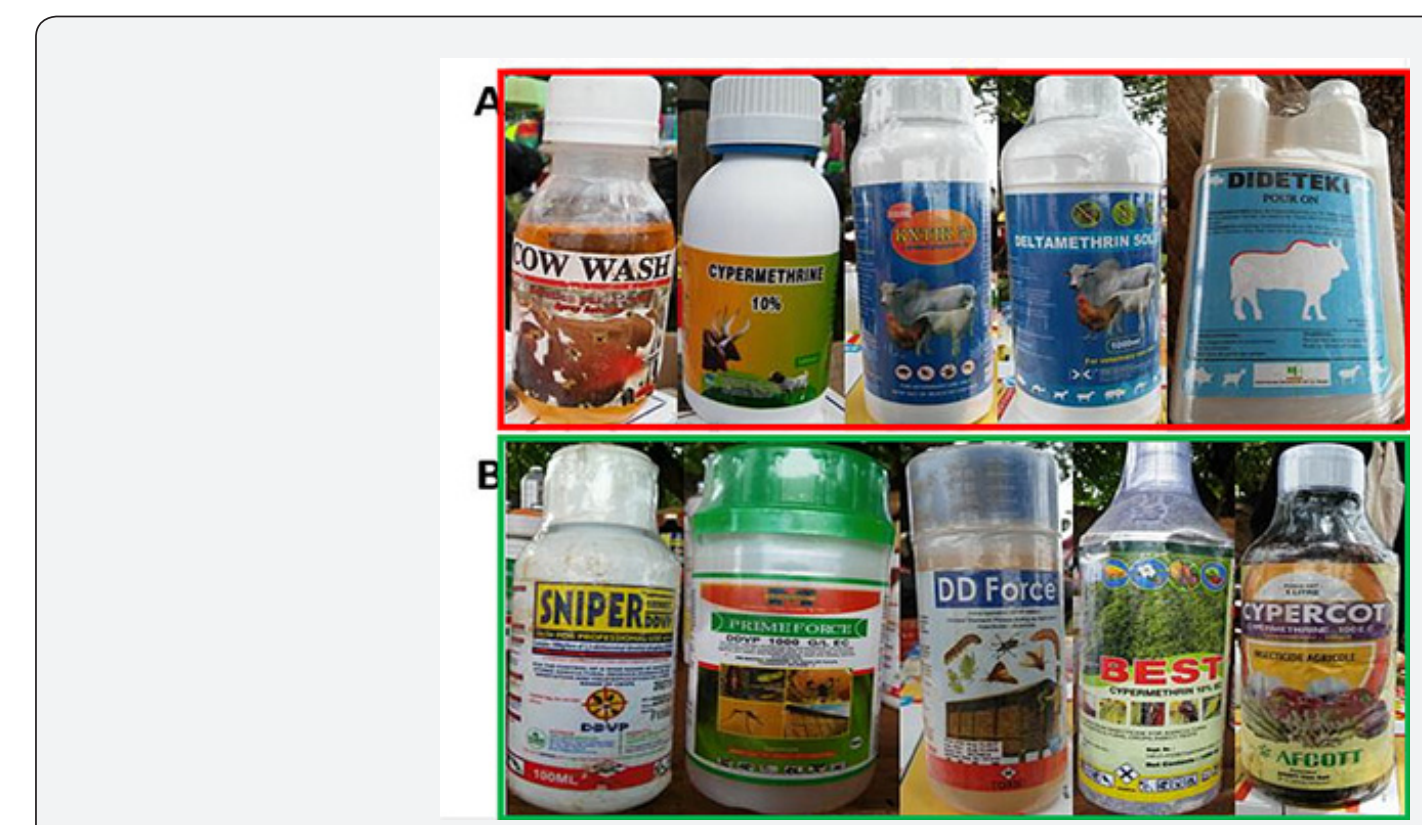

Figure 6: Insecticides prescribed by drug sellers for flies.

A: Veterinary insecticides (in red); B: Agricultural insecticides (in green).

Deltamethrin was commonly known by local Fulbe of Northern Cameroon as "Tegal” meaning insecticide. Deltamethrin was considered highly effective for flies and ticks by herders. About cost effectiveness, Deltamethrin like any other veterinary or ag- ricultural insecticide was retailed in $250 \mathrm{ml}$ (1500FCFA), $500 \mathrm{ml}$ (3500 FCFA) and $1000 \mathrm{ml}$ (7000 to 8000 FCFA) meaning that those who were unable to purchase in 1liters were able to get a quarter or half liters at cheaper rates (Table 5).

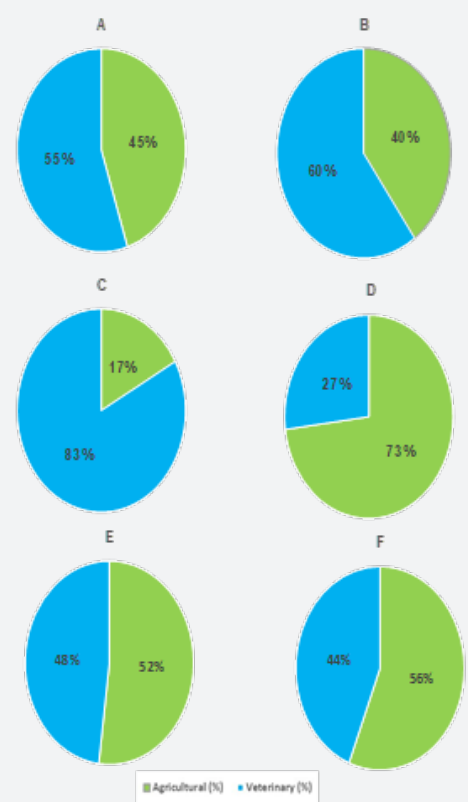

Figure 7: Proportion of drug sellers from different markets prescribing agricultural and veterinary insecticides for veterinary use. A: Mbidjoro; B: Tchabal; C: Galdi; D: Djalingo; E: Dibi; F: Dang

Drug dealers from Dang, Djalingo, Mbidjoro and Dibi testified that herdsmen purchased two agricultural insecticides to make a formulation to improve their efficacy for veterinary use (insec- ticides and acaricides) for example DD force ${ }^{\circledR}+$ CYPERCOT®,

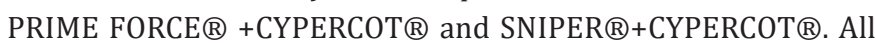
veterinary shops that were seen in the various cattle markets 
were simply a bench (Figure 8) onto which the drugs were displayed or a traditional tent with the inside having a bench on which the drugs were displayed. $75 \%$ of the cattle market drug sellers originated from the villages beside the market but $25 \%$ of them was from Ngaoundere and Meiganga.

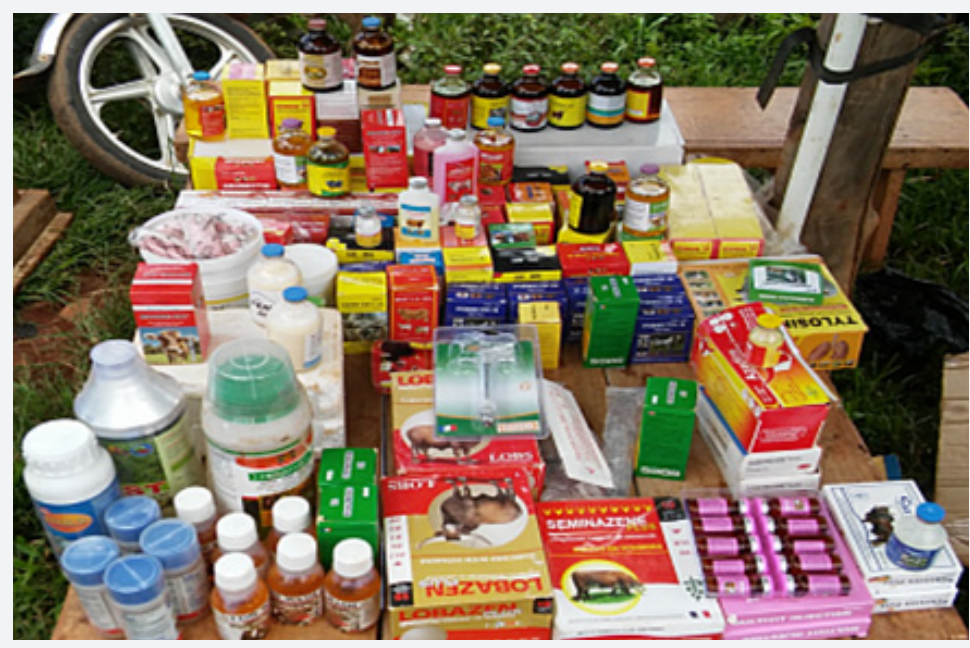

Figure 8: Drug shop at the Ngaoundere cattle market.

\section{Occurrence and origin of cattle and sheep in the various sites}

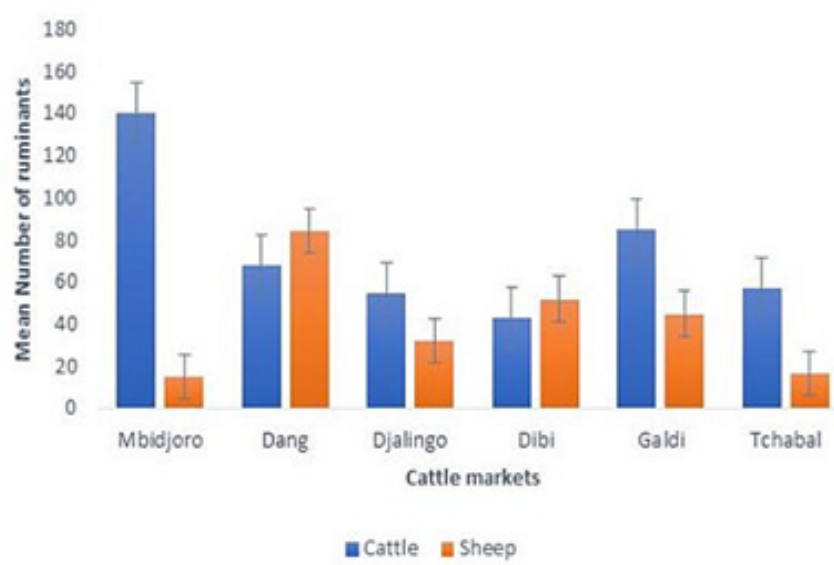

Figure 9: Mean number of ruminants sold in the various cattle markets prospected.

Veterinary chief of centers $(n=6)$ from each cattle market were interviewed on the occurrence of cattle/sheep as well as their origin. According to the veterinary chief of centers, low ruminant numbers were registered during the dry season due to transhumance. But the numbers gradually increased during the rainy season. For small ruminants, large numbers up to 100 and above were registered during festive periods usually in the months of July/August and December/January. For cattle, large numbers were registered in all the markets surveyed between June to October where numbers reached hundred and above. But low numbers were registered from January to May. Mbidjoro, Djalingo, Galdi and Tchabal recorded higher mean number of cattle than sheep, but only Dang and Dibi recorded high mean sheep numbers than cattle (Figure 9). There was an interconnection between all the cattle markets since cattle merchants bought cattle from one market to sell in the next. Some veterinary chief of centers explained to us the phenomenon of 'ac- companying cattle' meaning if cattle owners brought six heads of cattle, only two out of the six were intended to be sold. The role of the other four (accompanying animals) was to escort the mass and avoid the target heads (those to be sold) from escaping. Those accompanying cattle heads are risk in contracting very contagious diseases like FMD because they met cases from other areas and end up re-introducing them to herds. The ruminants encountered at the Tchabal market originated from Soukourwo, Tchabal baouro, Yala, Yala Yarna, Nargol, Majele, Saltaka. At the Mbidjoro market, ruminants originated from Ngaoundere, Tchabal, Mbang Foulbe, Dang, Mai borno, Ndougai, Mallo, Mandaorou, Mudje Pe. At the Dang market, ruminants originated from Licock, Djalingo, Marma, Nyambaka, Dibi, Martap, Ntoumboru, Mbijoro, Beka-Hossere, Beka-Mangare. At the Djalingo market, ruminants originated from Gop Rey, Ngang ha, Bila Ssora, Ndouar, Massola, Ngaoubam, Mboudjouk, Dena, Ndougeuelen, Mbaoure, Margelen, Samba, Mandjimi, Velambai, Ngaoussai, Mbiskelwal, Youpou, 
Ndaresalam, Madem, Forri, Yoko, Lafia Didango, Yoko Tondou, Balel, Mbaoure, Bantai, Soanjong, Sadool Yaya and Barsawo. At the Dibi market, ruminants originated from Dibi, Belel Dibi, Wouro Sangue, Djouroum, Fori and Sovangor. At the Galdi market, ruminants originated from Makol, Mbawa, Gada Vina, Katil Foulbe, Mayo Soma and Baldedjam.

\section{Discussion}

Due to the yearly occurrence and economic challenge of FMD in the Vina division of the Adamawa region of North Cameroon, $100 \%$ of the target population was aware of the disease. The highest frequency of occurrence of FMD in herds of the respondents was twice a year and more than half of the population incurred huge economic losses caused by FMD. This finding was like that of Jemberu et al. [23] in Ethiopia. The occurrence of the disease was seasonal with peak outbreaks reported from the month of August. Majority of the respondents witnessed peak out breaks around mid to end of the rainy season. This finding was like that recorded for the districts of the lake zone of Tanzania [24] where high FMD cases were witnessed in the rainy season. This present investigation revealed animal contact as a major source of FMD transmission. According to Motta et al. [2], animal contact was the most common source for the transmission of infectious agents in herds and occurred in cattle markets. This experience was well known as some of the herders practiced herd isolation as a preventive measure, but still complained that it was difficult since the main husbandry system of the region was the extensive type. The contact between wildlife and livestock populations was another major source of FMD spread [25] and farmer's knowledge on this issue can help to reduce the environmental spread of the disease. The use of veterinary pharmaceuticals in the management of the disease in the absence of a vaccine was common in Vina Division. Antibiotics were widely used for FMD management, followed by anti-parasitics (Diminazene and Ivermectin) and lastly by anti-inflammatories.

Another common management approach which was locally known as a preventive measure was the use of medicinal plants and traditional preparations which for them was costly but was able to manage the disease. It was interesting to know that an antibiotic known as Moore Oxy® (ASAN PHARMACEUTICALS (NIG) LTD) and common name "Likki Bauru" in Fulfude (meaning FMD drug in English) was the only trusted drug against FMD by herders. This Moore Oxy® was manufactured in Nigeria and was another brand of Oxytetracycline (antibiotic). Vougat et al. [26] reported the same brand of veterinary pharmaceuticals used by farmers in the Far North region of Cameroon for FMD management and after quality control analysis; they reported that such products were of poor quality. Furthermore, treatment failure, drug resistance of animal pathogens, and harmful drug residues in the human food supply could be the result of such drugs [26].

The role of arthropods in the transmission of infectious diseases was well known for some pathogens but not known for many others especially FMD. The pasture land of the Vina di- vision was densely infested by Stomoxys as compared to other biting fly-groups (tabanids, Ceratopogonids, Simulium, glossines, etc....). The high proliferation of this group of blood-sucking flies was due to their short life cycles [27] and their ability to breed in several types of substrates [13]. Their high abundance and nuisance together with their frequent contact with livestock are some of the aspects of its biology that can lead to their high suspicion as mechanical vectors of key enzootic diseases such as FMD. Lendzele et al. [15] reported a $40.3 \%$ FMD virus RNA recovery rate from the anatomical parts of wild Stomoxys niger niger during epidemics in Ngaoundere, for the first time in the history of the disease. This finding prompted us to structure questions to score ideas about the importance of this fly group and their local management in the absence of mass control activities.

It was exciting to know that $76.86 \%$ of the target populations could identify stable flies and distinguish them from other biting fly groups. Due to the huge economic impact caused by tsetse flies as main vector of bovine trypanosomosis in the Adamawa Plateau of Cameroon, farmers still considered tsetse as the most important vector of cattle diseases. After the disappearance of tsetse flies from the region, farmers now consider Stomoxys and tabanids to be the major pests of cattle. The activities of the MSEG focus on glossines after the last tsetse and trypanosomosis eradication campaign in 1994 and no such campaigns ever existed in Vina division as it was considered as a tsetse free zone. The current problems such as: reduced milk production, meat and high burden caused by Stomoxys and tabanids in the division in the absence of glossines prompted the MSEG to start pilot surveys to map-out their distribution. Respondents reported a seasonal occurrence of Stomoxys. The present study showed that knowledge on stable flies was high in herders of youthful age than old. This can be explained by the fact that due to the economic impact caused by tsetse flies in the past, elderly farmers focused on their control and neglected other biting flies like stable flies. Because tsetse was rarely seen biting cattle in the last few years in Vina, young adult herders could clearly identify other most nuisible group of arthropods like stable flies ("boubi pettel"), tabanids ("boubi manga") and ticks.

But older adults were only conversant with tsetse and ticks, with little interest and knowledge on the current nuisible biting flies of cattle. Based on herder's own knowledge, the peak-occurrence of stable flies was at the end of the rainy season. This was like the finding of Sevidzem et al. [19] who reported highest catches of Stomoxys during the rainy season in the Faro and Deo Division of the Adamawa Plateau. However, this rainy season abundance was related to the availability of several humid environments that favored their development. Fly management was mostly carried using Deltamethrin as bottles of this product were seen around herds and mostly demanded in cattle markets by cattle owners. The application frequency of Deltamethrin by most herders was twice in the rainy season and once in the dry season. It was noticed from the survey that agricultural insecticides were used for flies and tick control on animals. According 
to breeders, the following insecticide combinations: DD force $(\AA+-$ CYPERCOT $®$, SNIPPER $\AA$ + CYPERCOT $®$, PRIME FORCE $®+C Y-$ PERCOT ${ }^{\circledR}$ were effective against ticks and flies of cattle. Apart from agricultural insecticides, they also used Deltamethrin (veterinary insecticide) to manage flies and ticks.

\section{Conclusion}

Improving farmers' knowledge and identifying gaps regarding FMD epidemiology as well as exploiting farmer's knowledge on the use of medicinal plants and traditional preparations as management options are critical activities for an effective FMD control in the absence of a commercial vaccine. The fact that farmers were aware of common blood-sucking flies as major pests of cattle in the absence of glossines and use local management options to deal with them was already a breakthrough in reducing the spread of infectious disease such as FMD. Farmers of Djalingo, Dang and Galdi reported frequent outbreaks of FMD at the end of the rainy season (August-September), which corresponded to the peak occurrence periods of Stomoxyidae in these same areas. Antibiotics (especially Moore $0 x y \AA$ ) were widely used in the management of FMD. Veterinary insecticides were used but it was interesting to know that agricultural insecticides were used by some farmers in the place of veterinary insecticides. There was no commercial vaccine for FMD in all the cattle markets.

\section{Recommendations}

Mass education regarding clinical symptoms, routes of transmission, disease management, prevention and control of FMD in the absence of vaccination should be directed to cattle owners, traders and cattle assists during market days. Farmers should be sensitized on the poor quality of veterinary pharmaceuticals bought from markets as well caution on usage of veterinary insecticides for animal treatment and not agricultural insecticides for animal treatment. This mass education on FMD should be accompanied with emphasis on Stomoxys potential in the contaminative transmission of the disease as knowledge about them in certain areas of the Vina Division was null.

\section{Acknowledgement}

We are grateful to Mr Aboubakary for interpreting the questions in Fulfulde to non-French speaking Fulbe. We appreciate Kong Anita (DVM student) for assisting in the investigation. We thank the veterinary nurses present during market days in the various markets for understanding and explaining the importance of our work to the target population.

\section{References}

1. Minepia (2014) Ministère de l'Elevage, des Pêches et des Industries Animales. Annuaire des statistiques du sous-secteur Elevage, Pêche et Industrie Animales 2013.

2. Motta P, Thibaud P, Ian H, Saidou MH, Ngu NV, et al. (2017) Implications of the cattle trade network in Cameroon for regional disease prevention and control. Science Report 7: 43932.
3. Reid SM, Mioulet V, Knowles NJ, Shirazi N, Belsham GJ (2014) Development of tailored real-time RT-PCR assays for the detection and differentiation of serotype $0, A$ and Asia- 1 foot-and-mouth disease virus lineages circulating in the Middle East. Journal of Virological Methods, 207: 146-153.

4. Carrillo C (2012) Foot and Mouth Disease Virus Genome. In: Maria LG, Víctor R, ed. Viral Genomes - Molecular Structure, Diversity, Gene Expression Mechanisms and Host-Virus Interactions. Janeza Trdine Publisher. In Tech, Rijeka, Croatia p. 3-69.

5. Picado A, Speybroeck N, Kivaria F, Mosha RM, Sumaye RD, et al. (2010) Foot-and-Mouth Disease in Tanzania from 2001 to 2006. Transboundary and Emerging Diseases pp. 865-1682.

6. Reid SM, Ferris NP, Hutchings GH, Zhang Z, Belsham GJ, et al. (2002) Detection of all seven serotypes of foot-and-mouth disease virus by real-time, fluorogenic reverse transcription polymerase chain reaction assay. Journal of Virology Methods 105: 67-80.

7. Vosloo W, Bastos AD, Sangare O, Hargreaves SK, Thomson GR (2002) Review of the status and control of foot-and-mouth disease in sub-Saharan Africa. Review of Science and Technology 21: 437-449.

8. Cilek J (2003) Attraction of colored plasticized corrugated boards to adult stable flies, Stomoxys calcitrans (Diptera: Muscidae). Florida Entomology 86: 420-423.

9. Mullens BA, Lii K, Mao Y, Meyer JA, Peterson NG (2006) Behavioral responses of dairy cattle to Stomoxys calcitrans in an open field environment. Medical and Veterinary Engomology 20(1): 122-137.

10. Taylor DB, Berkebile DR, Scholl PJ (2007) Stable fly population dynamics in eastern Nebraska in relation to climatic variables. Journal of Medical Entomology 44: 765-771.

11. Barré N (1981) Les Stomoxys ou mouches boeuf à La Réunion. Pouvoir pathogène, écologie, moyen de lutte. Maison Alfort (France)-Groupement d'Etudes et de Recherches pour le Developpement de l'Agronomie Tropicale-IEMVT.

12. Campbell B, Whiter G, Wrightj E, Crookshank (1977) Effects of stable flies on weight gains andfeed efficiency of calves on growing or finishing rations. Journal of Economic Entomology 70: 592-594.

13. Mavoungou JF, Nguema RM, Acapovi GL, Koumba RZ, Mounioko F, et al. (2017) Breeding Sites of Stomoxys spp. (Diptera: Muscidae), a Preliminary Study in the Makokou Region (North-East-Gabon). Vector Biology Journal 2: 1 .

14. Sevidzem SL, Mamoudou A, Acapovi-Yao GL, Achiri M, Tchuinkam T, et al. (2016) First inventory of non-biting and biting muscids of North Cameroon. International Journal of Research in Biological Sciences 5: 12-20.

15. Lendzele SS, Abdoulmoumini M, Timoleon T, Garabed R, Renz A, et al. (2017) Risk factors for the Contamination of Stomoxys niger niger Macquart 1851 (Diptera: Muscidae) With the Foot-and-Mouth Disease Virus. Global Foot-and-Mouth Disease Research Alliance (GFRA) book of abstracts pp. 149.

16. Jori F, Alexander KA, Mokopasetso M, Munstermann S, Moagabo K, et al. (2015) Serological evidence of Rift Valley fever virus circulation in domestic cattle and African buffalo in Northern Botswana (2010-2011). Frontiers in Veterinary Science 2: 63.

17. Jori F, Vosloo W, Du Plessis B, Bengis R, Brahmbhatt D, et al. (2009) A qualitative risk assessment of factors contributing to foot and mouth disease outbreaks in cattle along the western boundary of the Kruger National Park. Review of Science and Technology 28: 917-931.

18. Hargreaves SK, Foggin CM, Anderson EC, Bastos AD, Thomson GR, et al. (2004) An investigation into the source and spread of foot and mouth disease virus from a wildlife conservancy in Zimbabwe. Review of Science and Technology 23: 783-790. 
19. Sevidzem SL, Mamoudou A, Woudamyata AF, Zoli PA (2015) Contri bution to the knowledge of ecodiversity and density of tsetse (Glossinidae) and other biting flies (Tabanidae and Stomoxyinae) in the fly controlled-infested livestock/wild life interface of the Adamawa plateau-Cameroon. Journal of Entomology and Zoology Studies 3: 329333.

20. Mamoudou A, Mbakou LM, Ngu NV, Sevidzem SL, Zoli AP, et al. (2016) Preliminary assessment of bovine trypanosomiasis and its vectors in Santa, Bali and Bafut Sub-Divisions of the, North West Region, Cameroon. International Journal of Biological and Chemical Sciences 10: 1-12.

21. Baldacchino F, Muenvorn V, Desquesnes M, Desoli F, Charoenviriyaphap T, et al. (2013) Transmission of pathogens by Stomoxys flies (Diptera, Muscidae): a review. Parasite 20: 26.

22. Goswami A, Sagar RL (1996) Development of cognitive learning scale to test the knowledge of livestock owners about vaccination against the contagious diseases. Journal of Veterinary and Animal Sciences 27: 32-37.

This work is licensed under Creative Commons Attribution 4.0 License

DOI: $10.19080 / J D V S .2019 .10 .555782$
23. Jemberu WT, Mourits MCM, Hogeveen H (2015) Farmers' intentions to implement Foot and mouth disease control measures in Ethiopia. PLOS ONE 10 (9): e0138363.

24. Genchwere JM, Kasanga CJ (2014) Spatial and temporal distribution of foot-and-mouth disease virus in the lake zone of Tanzania. Onderstepoort Journal of Veterinary Research 81(2): 4.

25. Miguel E, Grosbois V, Caron A, Boulinier T, Fritz H, et al. (2013) Contacts and foot and mouth disease transmission from wild to domestic bovines in Africa. Ecosphere 4: 51.

26. Vougat RRB, NgomTiédja T, Ziébé R, Foyet HS, Moritz M (2017) Quality of veterinary pharmaceuticals and their use by pastoralists in the Far North Region of Cameroon. Pastoralism: Research, Policy and Practice $7: 6$.

27. Gilles J (2005) Dynamique et génétique des populations d'insectes vecteurs. Les Stomoxys, Stomoxys calcitrans et Stomoxys niger niger dans les élevages bovins réunionnais. Universitéde La Réunion, La Réunion, France: 14

Your next submission with Juniper Publishers
will reach you the below assets
- Quality Editorial service
- Swift Peer Review
- Reprints availability
- E-prints Service
- Manuscript Podcast for convenient understanding
- Global attainment for your research
- Manuscript accessibility in different formats
( Pdf, E-pub, Full Text, Audio)
- Unceasing customer service
Track the below URL for one-step submission
https://juniperpublishers.com/online-submission.php

